\title{
Chronostratigraphic terminology at the Paleocene/Eocene boundary
}

\author{
Marie-Pierre Aubry \\ Department of Geological Sciences, Rutgers University, \\ 610 Taylor Road, Piscataway, New Jersey 08554, USA
}

William A. Berggren

Department of Geology and Geophysics, Woods Hole Oceanographic Institution, Woods Hole, Massachussetts 02543, USA, and Department of Geological Sciences,

Rutgers University, 610 Taylor Road, Piscataway, New Jersey 08554, USA

John A. Van Couvering

Micropaleontology Press, American Museum of Natural History, New York, New York 10024, USA

Jason Ali

Department of Earth Sciences, University of Hong Kong, Pokfulam Road, Hong Kong, China

Henk Brinkhuis

Laboratory of Palaeobotany and Palynology, University of Utrecht, Budapestlaan 4, 3584 CD, Utrecht, The Netherlands

Benjamin Cramer

Dennis V. Kent*

Carl C. Swisher III

Department of Geological Sciences, Rutgers University, 610 Taylor Road, Piscataway, New Jersey 08554, USA

Christian Dupuis

Géologie Fondamentale et Appliquée, Mons Polytechnics, Rue de Houdain, 9, B-7000 Mons, Belgium

Philip D. Gingerich

Department of Geological Sciences and Museum of Paleontology,

University of Michigan, Ann Arbor, Michigan 48109-1079, USA

Claus Heilmann-Clausen

Geologisk Institut, Aarhus Universitet, DK-8000 Aarhus C, Denmark

Chris King

David J. Ward

Department of Earth Sciences, University of Greenwich, Chatham, Kent, UK

Robert W. O'B. Knox

British Geological Survey, Keyworth, Nottingham NG12 5GG, UK

Khaled Ouda

Department of Geology, University of Assiut, Assiut, 71516 Egypt

Lowell D. Stott

Department of Geology, University of Southern California,

Los Angeles, California 90089-0740, USA

Medard Thiry

Ecole des Mines de Paris, 35, rue Saint Honoré, 77305 Fontainebleau, France

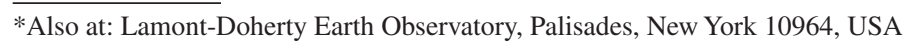

Aubry, M.-P., Berggren, W.A., Van Couvering, J.A., Ali, J., Brinkhuis, H., Cramer, B., Kent, D.V., Swisher, C.C., III, Dupuis, C., Gingerich, P.D., Heilmann-Clausen, C., King, C., Ward, D.J., Knox, R.W.O'B., Ouda, K., Stott, L.D., and Thiry, M., 2003, Chronostratigraphic terminology at the Paleocene/Eocene boundary, in Wing, S.L., Gingerich, P.D., Schmitz, B., and Thomas, E., eds., Causes and Consequences of Globally Warm Climates in the Early Paleogene: Boulder, Colorado, Geological Society of America Special Paper 369, p. 551-566. (C) 2003 Geological Society of America. 


\begin{abstract}
Integrated research over the past decade has led to the recognition of a short 150200 k.y.) interval of Paleogene time within Chron C24r at $55.5 \mathrm{Ma}$, formerly termed the late Paleocene Thermal Maximum (LPTM) but more recently the Paleocene-Eocene Thermal Maximum (PETM), that was crucial in the climatic, paleoceanographic, and biotic evolution of our planet. Stable isotope analysis of marine carbonates indicates that there were transient changes in surface and deep-water temperatures. These climatic changes coincided with a negative 3\%o-4\%o carbon isotope excursion (CIE), which is recorded in both marine and terrestrial deposits. It was soon realized that the CIE not only constitutes a powerful tool for long distance ("global") isochronous correlation, but even more importantly that it is coeval with notable biotic events in both marine and continental fossil records that have long been taken as criteria for the beginning of the Eocene in North America and more recently in deep sea cores. On the other hand, the conventional Paleocene/Eocene boundary level at the Thanetian/Ypresian boundary in Belgium and the London Basin has been found to be $\sim 1$ m.y. younger than the CIE, based on the association of the First Appearance Datum (FAD) of the (calcareous nannoplankton) Tribrachiatus digitalis (at $\mathbf{5 4 . 4}$ Ma) with the base of the Ypresian in the London Basin. Although the Ypresian definition would take priority under normal circumstances, a consensus has been reached to redefine the Eocene in recognition of the worldwide significance and correlatibility of stratigraphic features associated with the PETM.

Redefinition of the Eocene, however desirable, nevertheless cannot proceed in a stratigraphic vacuum, and this paper is concerned with resolving the consequences of this action. To be made coincident with the CIE at $\sim 55.5 \mathrm{Ma}$, the Ypresian/Thanetian boundary would have to be lowered by $\sim 1$ m.y., resulting in the inflation of the span of the Ypresian by $20 \%$ and a reduction of the span of the Thanetian by $30 \%$. At the same time, the terminology of the strata in the leapfrogged interval would be thrown into total conflict with the literature, with the substitution of one widely used stage name for the other in the conflicted interval. On the other hand, to relocate the Paleocene/Eocene boundary without moving the stage boundaries would result in the upper third of the Thanetian falling within the Eocene, demolishing a century-old consensus. We propose that the destabilizing effect of the new boundary in the classic chronostratigraphy of western Europe can best be minimized with the introduction of a pre-Ypresian Stage, to encompass the orphaned upper Thanetian interval as the basal unit of the Eocene under a separate name. To this end, we suggest the reintroduction of the Sparnacian Stage, now that its original concept has been shown to correlate essentially with the interval between the CIE and the FAD of $T$. digitalis.
\end{abstract}

\section{INTRODUCTION}

The redefinition of the Paleocene/Eocene boundary to coincide with the distinctive carbon isotope excursion (CIE) in Chron $\mathrm{C} 24 \mathrm{r}$ at $\sim 55.5 \mathrm{Ma}$ leaves the stratigraphic community with the essential task of reconciling the relocated series/epoch within the principles of chronostratigraphy. It is now commonly accepted that chronostratigraphy is a hierarchical discipline in which the stage is the lowest, basic unit (Hedberg, 1976; Cowie et al., 1986). We have reviewed elsewhere (Aubry et al., 1999) the conflicting treatment of chronostratigraphic hierarchy in the two primary authorities, the International Stratigraphic Guide (Hedberg, 1976; Salvador, 1994) and the Revised Guidelines of the International Commission on Stratigraphy (ICS) (Cowie et al., 1986; Remane et al., 1996). In regard to the role of the stage in defining chronostratigraphic boundaries, or Global Standard Stratotype-section and Points (GSSPs), we have argued that the approach taken by the Hedberg Committee is preferable, where these authorities conflict (Aubry, 2000; Aubry and Berggren, 2000a, 2000b; Aubry et al., 2000a, 2002).

In chronostratigraphy of the Cenozoic, far more than in earlier parts of the geologic continuum, age correlation is controlled by multiple independent criteria, not only in biostratigraphy, but also in terms of cyclostratigraphy, magnetostratigraphy, radioisotopic age determinations, stable isotope stratigraphy, and regional or global signals of large scale environmental changes. Using these overlapping controls, the relative age of well-characterized stratigraphic levels in the Neogene and 
Paleogene can normally be resolved to within 100 k.y., and frequently better than that. This means that the difference in age ( $\sim 1$ m.y.) between the CIE, a worldwide geochemical marker that reflects a sharp transient spike in global temperature at $\sim 55.5 \mathrm{Ma}$ (Berggren and Aubry, 1998) and the base of the Ypresian Stage at $\sim 54.4 \mathrm{Ma}$ (Aubry, 1996; Aubry et al., 1996) (both ages used here from Berggren and Aubry, 1998, for consistency with the time scale of Berggren et al., 1995), is significant. (The relationships between the lithostratigraphic units in northwestern Europe and the conventional chronostratigaphic units upon which they are based have been thoroughly discussed in Aubry [2000 and references therein] are therefore not repeated here.) In this paper we discuss the options for reconciling the lack of synchrony between the base of the Ypresian in the London-Paris Basin, historically and for many workers still the undisputed criterion for the base of the Eocene, and the level of the CIE, which the Paleocene/Eocene Working Group of the International Subcommission on Paleogene Stratigraphy has recently agreed to make the guide for selecting a new GSSP for the basal stage of the Eocene Series. Our aim is to suggest how the new concept of the Eocene can be established in accordance with the hierarchical standards recommended under the International Guidelines, and in consistency with principles outlined in the ICS Guidelines.

\section{HISTORICAL BACKGROUND}

We have little doubt that it will be necessary hereafter to intercalate other periods, and that many of the deposits, now referred to a single era, will be found to have been formed at very distinct periods of time ... [. . . . . we might have three divisions of the Eocene epoch,- the older, middle, and newer; [ . . ] In that case, the formations of the middle period must be considered as the types from which the assemblages of organic remains in the groups immediately antecedent or subsequent will diverge. (Lyell, 1833, p. 57)

Despite Lyell's foresight, the introduction of the Paleocene Epoch by Schimper (1874) — which represented a fulfillment of Lyell's vision of "the older" Eocene-met with unrelenting resistance. It took $>65 \mathrm{yr}$ for the Paleocene to become accepted by stratigraphic bodies in North America and almost $100 \mathrm{yr}$ for continental Europe to follow. Whereas, in retrospect, Lyell's insight and Schimper's initiative can only be praised, we should be aware of the train of thought underlying their approach, which is espoused to this day by a large part of the scientific community, although it is divorced from the philosophy of modern chronostratigraphy. Current controversies (e.g., Aubry et al., 1999, 2000a; Aubry and Berggren, 2000a, 2000b; Remane, 2000; Walsh, 2001) in chronostratigraphic procedures can be understood as a consequence of this dual thinking.

Lyell built a chronologic framework that recognized time before rock. His subdivisions are based on a succession of fossil assemblages arranged according to internal evidence of their antiquity, and not on rock units. Formations, grouped in Series, are fitted to Epochs on the basis of their molluscs and echinoderms. For Lyell, the Eocene Epoch was known before the
Eocene Series. Applying modern language, Lyell saw chronology as synonymous with biochronology. His Classification of Tertiary Formations in Chronological Order is alien to chronostratigraphy, a concept that was to be developed later.

Schimper (1874) followed precisely in Lyell's steps when he introduced the Paleocene Epoch, and so did the paleontologists and stratigraphers who first saw the appropriateness of an older Eocene interval. Schimper characterized the Paleocene not by its stratigraphic units, but by its flora "directly related to the Heersian flora, itself very close to the Cretaceous flora, and even more to the flora of the Eocene Epoch, but with a distinctive aspect which characterises it at once" (translated from Schimper, 1874, p. 464). Similarly, the Wood Committee (Wood et al., 1941) characterized the Paleocene in terms of its North American Land Mammal Ages (NALMA) and many vertebrate paleontologists have followed this path to this day. For example, Archibald et al. (1987, p. 25) stated, "We consider mammal age and mammal zones to be a type of biochronological unit, a unit that is not used by the NASC and is only briefly considered by the ISG. Such units are characterized by faunal content."

The mammalian turnover recorded between the upper Clarkforkian and lower Wasatchian beds in North America and the Cernay and Meudon Conglomerates in Europe (Granger, 1914; Wood et al., 1941; Russell, 1967, 1968; Gingerich, 1989) was instrumental in convincing European stratigraphers, who had worked hard for almost a century to reduce Schimper's Paleocene concept to a non sequitur, to see the Paleocene as a useful concept after all. Pomerol $(1969,1977)$ found in this prominent turnover a justification for proposing the base of the Sparnacian Stage as the definition for a revived Paleocene/ Eocene boundary (Fig. 1, column $\mathrm{H}$ in association with columns E and G). Although Pomerol's proposal could have constituted the ultimate reconciliation between different schools of thought, it proved only to increase discord. According to Pomerol, the base of the Sparnacian was appropriate for the base of the Eocene primarily because the Conglomérat de Meudon-the mammalbearing formation interpreted as immediately younger than the faunal turnover-was understood to lie at the base of the Sparnacian Stage. This point of view, reinforced by the subsequent correlation of the basal Zone Wa0 of the Wasatchian NALMA to the Conglomérat de Meudon (Gingerich, 1989), was essentially a validation of the Lyellian geohistorical approach, with its assumption that the Paleocene/Eocene boundary should be defined by a paleobiologic event. Unfortunately, this assumption was inconsistent with the advanced chronostratigraphic principles that had more recently become accepted by the general stratigraphic community.

In the late 1940s the International Subcommission on Stratigraphic Classification (ISSC), chaired by Hollis Hedberg, began to outline principles of definition and practice that were eventually brought together in the Guide to Stratigraphic Classification (Hedberg, 1976). This work elevated the earlier efforts in various national groups to a new level of logical philosophy that established chronostratigraphy as the independent means of defi- 
nition for temporal reference. Notably, the ISSC proposed the stage as the basic unit in the hierarchy of chronostratigraphy (Hedberg, 1972, 1976; Salvador, 1994). Following the guiding principle of field geology that observation precedes interpretation, the Hedbergian school built on the logical premise that recognized rock before time. The subdivisions of geological time, in this view, are directly based on rock units rather than on indirect inferences about relative antiquity, or on the age of inferred events that were derived from paleontologic changes such as those observed by Lyell. The definition of geological ages thus follows from the definition of stages as the basic units of chronostratigraphy. This is in accord with the original definition by d' Orbigny (cf. Aubry et al., 1999), which clearly understands the stage as a unit of geological time defined in strata that record events of the same age. As marine stratigraphers attempted to unravel correlations between formations on various continents and deep-sea deposits recovered by the nascent Deep Sea Drilling Project, much concerted effort was devoted to the definition of chronostratigraphic boundaries. The standard chronostratigraphic scale was born as the boundaries between series became tied to those between stages (Berggren, 1971). The names of Lyell's subdivisions were retained but the concept and content of series were altered to fit modern (chrono)stratigraphic concepts. The base of the Eocene thus became tied to the base of the Ypresian Stage, following the pioneering work of von Koenen (1885; Fig. 1, columns A, D and $\mathrm{F}$; see discussion below).

Two definitions of the Paleocene/Eocene boundary had thus emerged. One (Fig. 1, column $\mathrm{H}$ in association with columns $\mathrm{E}$ and $\mathrm{G}$ ), identified the beginning of the Eocene with a major paleobiologic event observed at the base of a continental lithologic unit (e.g., Wood et al., 1941; Pomerol, 1969, 1977; Archibald et al., 1987; Gingerich, 1989) referred to by some as Sparnacian Stage (e.g., Russell, 1968; Pomerol, 1969, 1977; Russell et al., 1982; Savage and Russell, 1983), much in the tradition of Lyell's thought. The other, in which the base of the Eocene is inherent in the definition of the base of the Ypresian Stage (Fig. 1, columns A and F), was followed in observance of the hierarchical principles espoused by the international stratigraphic community (Hedberg, 1976; Salvador, 1994).

\section{CURRENT (PRE-GSSP) UPPER PALEOCENE-LOWER EOCENE STANDARD CHRONOSTRATIGRAPHIC FRAMEWORK}

Intense research and debate, continuing to the present generation, supports the consensus that two stages typified in the Paris-London Basin, Thanetian and Ypresian, constitute the primary reference for upper Paleocene-lower Eocene chronostratigraphy. In the hierarchical logic of chronostratigraphy, the Thanetian/Ypresian boundary simultaneously determined the Paleocene/Eocene boundary. A discussion of the role of these stages in the changed concept of the Eocene Series recommended by the International Commission on Stratigraphy (ICS) requires a fresh evaluation of the consensus. Rehabilitation of the Sparnacian Stage, which has suffered from inconsistent and preconceived treatment, appears to be crucial in reconciling the new concept of the Eocene with stability in global chronostratigraphy.

The introductions of the Ypresian, Sparnacian and Thanetian Stages are part of a late nineteenth century effort at describing stratigraphic successions in northwestern Europe and at sorting out correlations between disjunct stratigraphies in the Belgium, Paris and London basins (Figs. 1, 2). An extensive historical review of this effort is given in Aubry (2000).

\section{The Ypresian Stage}

The Ypresian Stage was defined by Dumont (1839) in Belgium, near the town of Ypres. Numerous studies over the succeeding one hundred and $50 \mathrm{yr}$ established a firm framework of correlation between the Thanetian and Ypresian successions of Belgium, the London-Hampshire Basin(s), and the Paris Basin, such that the Ypresian Stage has acquired a strong regional significance (see Knox, 1994). The commonly accepted base of the Ypresian Stage is the base of the Mont Héribu Member of the Ieper Formation, Belgium (De Coninck et al., 1983). This level is correlative with the Walton Member at the base of the London Clay Formation, England, and the base of the Sables de Cuise s.1., Paris Basin (Fig. 2; Aubry, 2000, Figure 4). Because it is precisely correlated to the Thanetian-Ypresian succession in Belgium (Ali et al., 1993; King, 1991), the more marine-and thus more amenable to correlation with the deep sea-ThanetianYpresian succession in England has become the reference for upper Paleocene-lower Eocene chronostratigraphy. This succession in the London Basin has been formalized to comprise the Thanet Formation, the Lambeth (Upnor Formation and Woolwich-Reading Formation) Group and the Thames (Harwich Formation and London Clay Formation) Group (Ellison et al., 1994). Following the chronostratigraphic principles of the International Stratigraphic Guide, the base of the Eocene is thus tied to the base of the London Clay Formation, where it has in fact been identified for well $>120 \mathrm{yr}$, in agreement with von Koenen (1885) who placed the Paleocene/Eocene boundary in England between the Thanetian deposits and the London Clay based on analysis of molluscan faunas (Fig. 1, column F). Importantly the base of the London Clay Formation has been indirectly tied to the First Appearance Datum of Tribrachiatus digitalis (Aubry, 1996) whose estimated age of 54.4 Ma (Aubry et al., 1996; Berggren and Aubry, 1996) was proposed to approximate the age of the base of the Ypresian Stage. This proposal has been validated with the recovery of $T$. digitalis in the Basement Bed (= upper Harwich Formation) that lies immediately below the Walton Member (Fig. 2).

The term Ypresian has also been used in a different-and incorrect-chronostratigraphic context. Below the base of the stratotypic Ypresian in northwest Europe, the Argiles Plastiques in the Paris Basin and the Sables d'Erquelinnes in Belgium cor- 


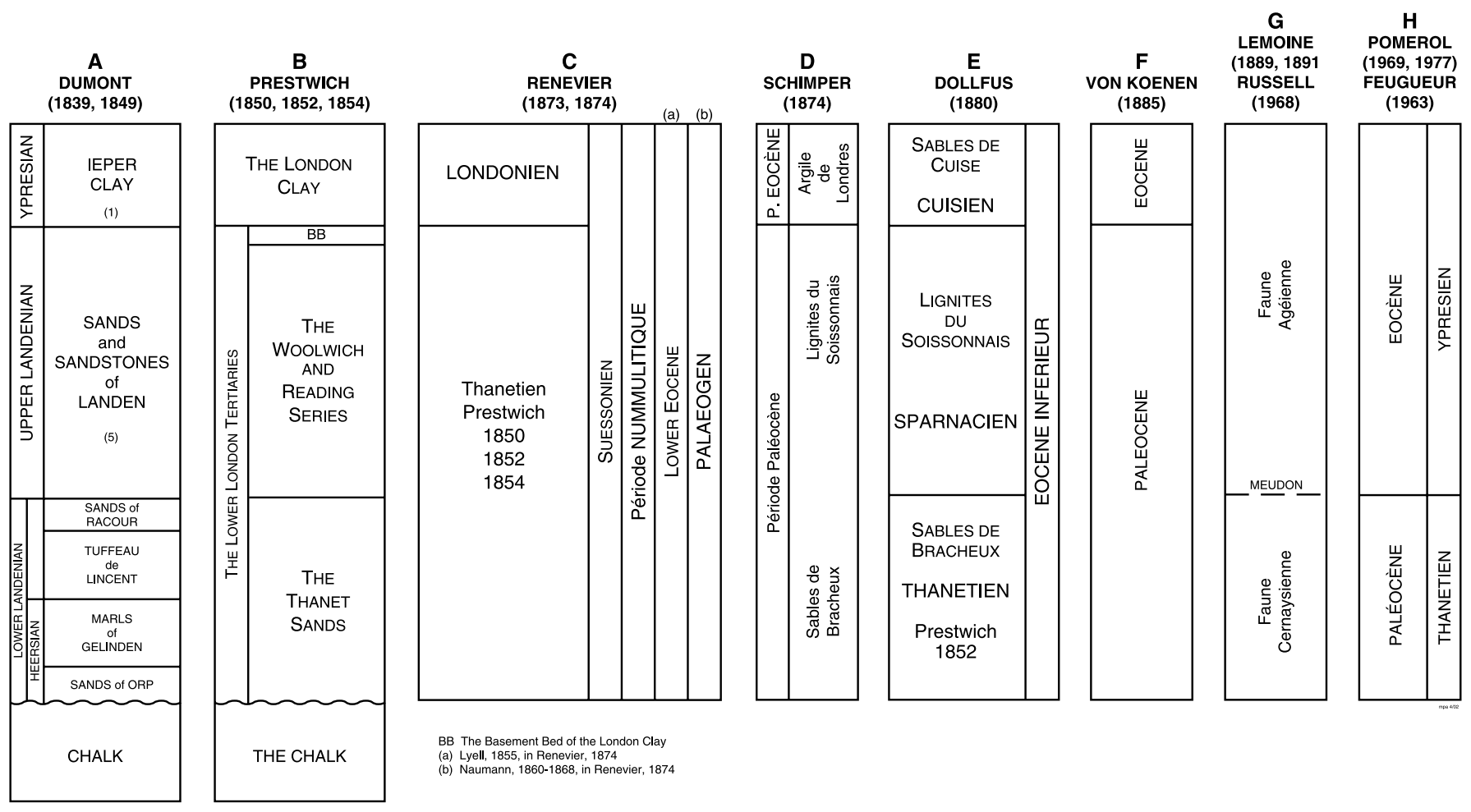

Figure 1. Historical review of the lithostratigraphic units of northwest Europe that have served as references for upper Paleocene-lower Eocene chronostratigraphy until the recent designation of a GSSP for the Paleocene/Eocene boundary. Note that the terms are presented in the format they were introduced. Two schemes of references were established in parallel, one in which lithostratigraphic horizons and units served as basis for the designation of stages (columns A-C, E), another in which paleontologic changes were used to designate epochs (column D) and their boundary (column H). (Modified after Aubry, 2000).

relate with the Woolwich-Reading Formation in the London Basin (Fig. 2). In contrast with most of his contemporaries, Feugueur (1963) believed in age equivalence between the Argiles plastiques, the London Clay and the (lower) Ypresian clays, based on facies similarity and apparent faunal equivalence (Fig. 1, column $\mathrm{H}$ in association with columns $\mathrm{E}, \mathrm{B}$ and $\mathrm{A}$ and Figure 2). This miscorrelation implied that the Sparnacian Stage (Dollfus, 1880), represented in the Argiles plastiques, was equivalent with the lower part of the Ypresian Stage of Dumont (Fig. 1, columns A and E; Fig. 2). Because the Sparnacian had long been identified with the upper part of the Thanetian, Feugueur's view meant that the lower part of the Ypresian Stage would overlap with the upper part of the Thanetian Stage sensu Renevier (Fig. 1, H and C). When placing the Paleocene/Eocene boundary at the base of the Sparnacian Stage on the basis of the mammalian turnover event, Pomerol $(1969,1977)$ perpetuated Feugueur's miscorrelation by essentially accepting the view that the base of Dollfus' Sparnacian was correlative with the base of Dumont's Ypresian (Fig. 1, compare columns E and H with columns E and A). Two concepts of Ypresian Stage had now emerged, although few stratigraphers followed Pomerol's view. Nevertheless this created a further complication (see below).

\section{The Sparnacian Stage}

Dollfus (1880) introduced three stages: Thanetian, Sparnacian and Cuisian (Fig. 2) (unaware that a Thanetian Stage had already been established by Renevier, 1873; Figure 1, compare columns $\mathrm{C}$ and $\mathrm{E}$ ). His main objective was to substitute the Cuisian for Dumont's Ypresian, whose stratotype he saw as unsatisfactory. Dollfus did not immediately propose a stratotype for his Sparnacian, but he clearly delineated its lithostratigraphic extent, in particular with reference to the London Basin succession. Importantly, Dollfus used sequence stratigraphy much before its time, recognizing that the Lignites du Soissonnais and the Reading-Woolwich Beds on the one hand, and the Sables de Sinceny and Oldhaven/Basement Bed on the other hand represented correlative packages separated by erosion surfaces at the same time as the correlative packages rested unconformably over, respectively, the Thanet Sands and their French equivalents (Sables de Bracheux s.1.) and below the Sables de Cuise and the London Clay (Fig. 2). From its introduction, the Sparnacian Stage thus contained the criteria required for sound chronostratigraphic units with one exception (acknowledged by Dollfus, 1905) that it was based primarily on continental and brack- 


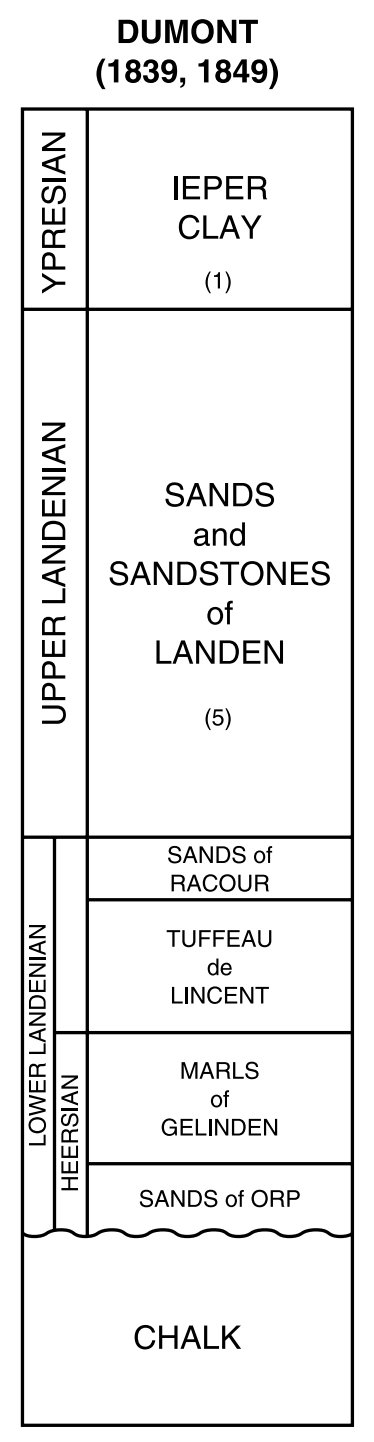

DUMONT
PRESTWICH $(1850,1852,1854)$ RENEVIER (1873)

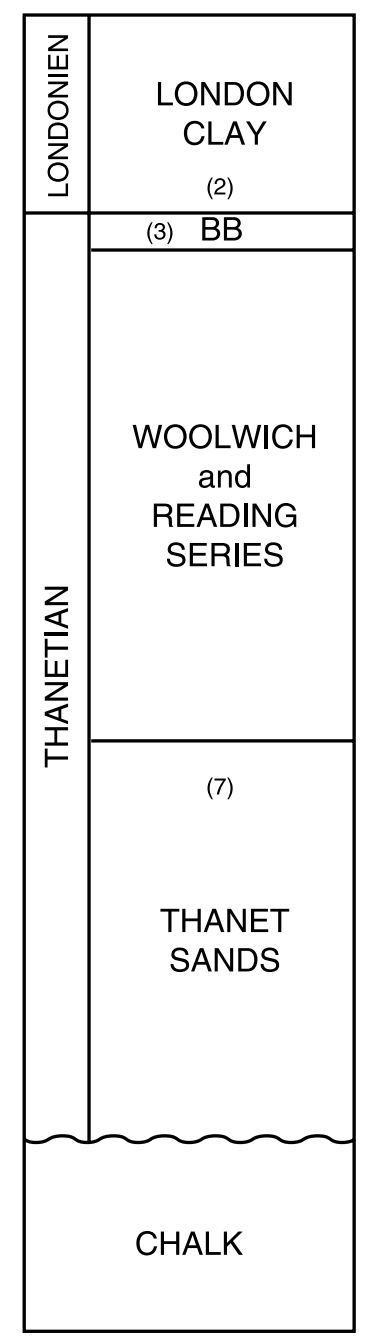

DOLLFUS

(1880)

\begin{tabular}{|c|c|}
\hline$\frac{z}{\frac{z}{\omega}}$ & $\begin{array}{c}\text { SABLES } \\
\text { de } \\
\text { CUISE }\end{array}$ \\
\hline 崩 & $\begin{array}{c}\text { LIGNITES } \\
\text { du } \\
\text { SOISSONNAIS } \\
\text { (6) }\end{array}$ \\
\hline 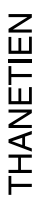 & $\begin{array}{c}\text { SABLES } \\
\text { de } \\
\text { BRACHEUX }\end{array}$ \\
\hline & CHALK \\
\hline
\end{tabular}

Figure 2. Relationships between the stages defined in the Belgian (Dumont, 1839, 1849), London (Renevier, 1873) and Paris (Dollfus, 1880) basins that have served in the standard chronostratigraphic scale (e.g., Berggren et al., 1985, 1995; Harland et al., 1990, i.al.) until formal definition of chronostratigraphic boundaries in the form of Global Standard-stratotype Section and Points become mandatory. Note that the terms are presented in the format they were introduced, as in Figure 1. We have added the lithostratigraphic units in the Landenian Stage given in Laga (1981) and we show the location of stratigraphic units discussed in the text: (1) Mont Héribu Member; (2) Walton Member; (3) Oldhaven Beds = Basement Bed of the London Clay $(\mathrm{BB})=$ upper part of the Harwich Formation; (4) Sables de Sinceny; (5) Sables d'Erquelinnes; (6) Argiles Plastiques; (7) Upnor Formation (= Woolwich Bottom Bed). Discussion of the content of the stages can be found in Berggren (1971), Cavelier and Roger, (1980) and Pomerol (1981) (modified after Aubry et al., 1999). ish deposits (although the shallow marine Sables de Sinceny are part of the definition).

What Dollfus did not recognize, when he later (1905) designated the Mont Bernon section (near Epernay) as the stratotype of the Sparnacian Stage, was that his type designation and his stage definition (1880) were irreconcilable. The type-section is much younger than the original definition, being of Cuisian (Ypresian) Age (Laurain et al., 1983). This inconsistency largely contributed to the dismissal of the stage by some (e.g., Hooker, 1996, 1998), regardless of 1) Dollfus' clear definition and sound correlations and 2) the extreme difficulty in establishing a sound lithostratigraphic framework for the lignite-bearing clays of the Paris Basin, including the Mont Bernon section (Thiry et al., 1998). Cavelier and Pomerol (1986) proposed to use the term "Sparnacian s.s." in a regional sense, according to the definition of Dollfus, while other authors (e.g., Laurain et al., 1983; Hooker, 1998) chose to restrict the Sparnacian to its stratotype.
Aubry (2000) recognized the clarity of Dollfus' definition and the validity of his correlations between the London and Paris Basin stratigraphies, which have been well corroborated by numerous studies (e.g., Curry et al., 1978), and even more importantly, the significance of his early descriptions of sequences.

\section{The Thanetian Stage}

The Thanetian Stage, as it is used today, essentially corresponds to the Thanetian Stage erected by Renevier (1873; Fig. 2), to encompass Prestwich's description of the "Lower London Tertiaries" (Fig. 1, columns B and C). Intercalated between the Chalk and the London Clay, these strata consisted of the Thanet Sands (Prestwich, 1852), the Woolwich and Reading Series (Prestwich, 1854) and the "Basement Bed of the London Clay" (Prestwich, 1850; now the upper part of the Harwich Formation of Ellison et al., 1994). On the other hand, the Thanetian Stage 
of Dollfus was restricted to the Thanet Sands, while his Sparnacian Stage included the Woolwich and Reading Series and Basement Bed of the London Clay (Fig. 1, compare columns B and E). Thus, broader and narrower concepts of the Thanetian Stage have been utilized, the narrower concept being applied by those who accepted the Sparnacian Stage. The broader concept of Thanetian, heretofore in somewhat wider use than the narrower, is inconsistent with the new concept of Eocene, in which the definitions of Ypresian and Thanetian as lowermost Eocene and uppermost Paleocene stages, respectively, are inconsistent with a series boundary linked to the CIE.

\section{Discussion}

The upper Paleocene-lower Eocene chronostratigraphy in the Paris-London Basin, as described above, is marked by inconsistency — both conceptual and terminological—from very early on, due to unawareness of published material and genuine miscorrelation. It is important to note, however, that the shallowmarine and epicontinental nature of the stratigraphy under scrutiny makes any attempt at regional correlation difficult under the best circumstances.

One major conflict has been the placement of the Paleocene/ Eocene boundary at the base of the Ypresian Stage by most marine stratigraphers, and at the base of the Sparnacian Stage by most vertebrate paleontologists. Another example has been the identification of the beginning of the Eocene by some as corresponding to the moment when a lithostratigraphic horizon was being deposited, while others have seen it as the moment when a paleobiologic event occurred. Finally, there has been a basic dualism in definition of the stages themselves, wherein two parallel concepts of Thanetian Stage are in active use, and the definition of the Sparnacian Stage is disconnected from the designation of its stratotype. These problems with the definition and characterization of chronostratigraphic units are quite apart from the further problems of their global correlation (see Berggren and Aubry, 1996, 1998; Aubry, 2000).

The definition of a GSSP for the Paleocene/Eocene boundary is thus a welcome endeavor, a chance to clarify definition and means of correlation in this important area of classical stratigraphy for the benefit of the entire geological community. In recognizing the value of the CIE as a clear and unambiguous criterion for the new GSSP we hope that it also provides an opportunity for reconciliation of the various conflicts identified above. For example, even though the new GSSP level serendipitously coincides with the Lyellian (i.e., paleobiologically defined) Paleocene/Eocene boundary favored by vertebrate paleontologists and some deep sea workers, such alternative methods of definition will henceforth cease to be relevant.

With regard to the relationship of the Paleocene/Eocene GSSP to the chronostratigraphy of the Paris-London basin, in which Eocene and Paleocene series were originally recognized, and which has become a de facto global standard, we now have the benefit of such tools as carbon isotope stratigraphy in par- ticular, but also an improved biozonal subdivision based on microfossils (planktonic and benthic foraminifera, calcareous nannoplankton and dinoflagellates) associated with the isotopic excursion and finally, radioisotopic dating and astrochronology. In applying this information, we have taken a position that we believe is consistent with the hierarchical logic of chronostratigraphy, if not the requirements of the current ICS Guidelines (Aubry et al., 1999, 2000a), which is that the newly proposed series boundary should be defined in the context of a framework of globally correlatable stages. To this end, we have suggested a solution that we hope will be seen as a satisfactory reconciliation of practical goals and fundamental principles.

\section{RECONCILED CONCEPT OF THE PALEOCENE/EOCENE BOUNDARY}

The late Paleocene-early Eocene transition was characterized by a marked global warming, particularly at high latitudes, reflected in evolutionary turnovers, diversification, and migrations as well as extinctions that are recorded over a span of $\sim 2$ million years in both marine and terrestrial environments. This warming, in turn, was punctuated by a brief $(<0.1$ m.y.) extreme ocean warming event (formerly known as the late Paleocene Thermal Maximum and now termed the Paleocene-Eocene Thermal Maximum (PETM), and was associated with the CIE, a large $(\sim 3 \%-4 \%)$ negative excursion in $\delta^{13} \mathrm{C}$ first recognized in planktonic and benthic foraminifera (Kennett and Stott, 1991).

The marine biotic response to the brief climatic warming is seen in the form of a series of events that have been recognized in the calcareous and organic walled plankton and calcareous and agglutinated benthos (Berggren et al., 1998) at/near the PETM. These are enumerated below.

Calcareous nannoplankton. The onset of the CIE is marked by the sudden appearance of species (e.g., Discoaster anartios, D. araneus, Rhomboaster spp.) with unusual morphology and structure that for a short time dominated all PETM/CIE assemblages in the Tethys and Atlantic area (Cramer et al., 1999; Aubry et al., 2000b). Superimposed on this short-term event, a long-term turnover was initiated with the onset of the CIE, leading to the extinction of taxa that radiated during the Paleocene and the evolution of several modern structural groups. Of particular significance for the Chron C24r stratigraphy/chronology is the evolution of the Rhomboaster-Tribrachiatus lineage, which permits the subdivision of the NP9-NP10 zonal interval into six subzones.

Planktonic foraminifera. Muricate, nonspinose (sub)tropical morozovellids and their geographically more widespread nonspinose, bluntly muricate acarininid cousins increased in abundance and expanded into high southern (Kerguelen Plateau, Maud Rise, South Atlantic) as well as northern (London Basin, North Sea) latitudes, while a distinct association of small acarininids (Acarinina africana and A. sibaiyaensis) and a lone morozovellid (Morozovella allisonensis) taxon-the so-called "excursion fauna"-characterized the PETM.

Benthic foraminifera. Deep-sea (bathyal and abyssal) ben- 
thic foraminifera underwent the largest $(>50 \%)$ essentially global extinction/taxonomic turnover in $>70$ million years (since the mid-Cretaceous Cenomanian/Turonian boundary, Thomas, 1998). This event is referred to as the Benthic Foraminiferal Extinction Event. A global, cosmopolitan, taxonomically diverse fauna (characterized by the taxon Stensioina beccariiformis) was replaced by a fauna dominated by Nuttallides truempyi, commonly in mid-to-lower bathyal and abyssal Atlantic Ocean (and specifically South Atlantic) sites. At many other oceanic sites, and in Tethyan bathyal sections in Spain, postextinction faunas are dominated by various buliminid taxa. Postextinction faunas vary widely, are all of low diversity, and contain small, thin-walled individuals (if calcareous). A lesser, but nevertheless recognizable, event occurred in neritic/ shelf environments as well (Speijer, 1994; Cramer et al., 1999).

Dinoflagellates. Associated with the CIE interval was the first global increase in Apectodinium-dominated assemblages (Bujak and Brinkhuis, 1998; Crouch et al., 2000). Subsequently, close to the beginning of the Ypresian Age (as determined by the base of the conventional (pre-GSSP Ypresian Stage) there was an increase in new dinocyst taxa, including the Deflandrea phosphorica group, and a concomitant increase in diversity within the Wetzelielloideae (Wetzeliella, Charlesdowniea and Dracodinium) (Bujak and Brinkhuis, 1998; Egger et al., 2000; Heilmann-Clausen and Egger, 2000).

The terrestrial Paleocene-Eocene transition coincides with the CIE and is marked by significant turnovers in mammalian faunas. Turnovers in the plant floras occurred more progressively.

Mammals. A significant and relatively rapid appearance/ incursion (mammal dispersion event, MDE) of the earliest representatives of perissodactyls (odd-toed ungulates), artiodactyls (even-toed ungulates) and euprimates and rodents (Rose, 1981; Gingerich, 1989, 2001) as well as extinction of the larger plesiadapids in the Bighorn Basin is seen also in contemporary levels in Europe (Paris-London Basins) and Asia (Rose, 1981; Russell and Zhai, 1987).

Plants. The Paleocene-Eocene transition in North America witnessed a $\sim 30 \%$ diminution in the number of plant species (Frederiksen, 1994; Wing et al., 1995, 2000; Wing, 1997) over an interval of $\sim 1$ m.y., followed by a rapid rebound to levels well in excess of pre-PETM floral richness in the mid-early Eocene, reflecting the trend toward higher global temperatures associated with the Cenozoic Global Climatic Optimum. The Paleocene-Eocene turnover consisted of a replacement of largely deciduous groups with modern north temperate distribution (Betulaceae, Cercidiphyllaceae, Juglandaceae, Hamamelidaceae, Metasequoia) by largely subtropical evergreen groups (Annonaceae, Lauraceae, Leguminosae, Myristicaceae, Palmae, Zamiaceae, i.al.) (Wing, 1997). Similar patterns have been recorded in Gulf Coastal Plain (Frederiksen, 1994), North Sea (Jolley, 1996) and New Zealand (Crouch, 2001) palynofloras, attesting to the essentially global nature of these changes.
Of particular interest in the context of our discussion is the climatic implications of leaf margin analysis (Wing et al., 2000) on Bighorn Basin assemblages: (1) mean annual temperatures on the order of $12.9-15.3{ }^{\circ} \mathrm{C}$ during the Clarkforkian, (2) earliest Wasatchian mean annual temperatures of $18.2{ }^{\circ} \mathrm{C}$ followed by (3) decline to $16.4{ }^{\circ} \mathrm{C}$ and then $10.8{ }^{\circ} \mathrm{C}$ at an (interpolated) age of 53.56 Ma (youngest part of Chron C24r), and (4) midWasatchian rise to $15.8^{\circ} \mathrm{C}$, eventually rising to $22.2^{\circ} \mathrm{C}$ by 52.8 Ma (Chron C24n.1n) near the beginning of the Lostcabinian Subage of the Wasatchian NALMA (mid-Ypresian).

These then are the bio- and chemostratigraphic events that have shaped the discussion and debate within the Paleocene/ Eocene Boundary Working Group over the past decade regarding criteria suitable for correlating the Paleocene/Eocene boundary. The recognition of a succession of distinct, closely juxtaposed events associated with an unmistakable isotopic signal in marine and nonmarine contexts alike justifies the recommendation that the Paleocene/Eocene boundary should be defined at a level coincident with the CIE, as the most widely applicable criterion for global correlation. In consequence, however, one is confronted by the problem of what to do with the boundaries of the stages that formerly defined the Paleocene/Eocene boundary in its original context. We consider this point in further detail below.

\section{THE PALEOCENE/EOCENE BOUNDARY GSSP}

The place given to the stage by ICS revised guidelines is currently inconsistent (Aubry et al., 1999, 2000a). On the one hand, the stage is the basic unit of chronostratigraphy; but on the other hand, in use the stage has been subservient to series, in the sense that stage boundaries have been defined by series boundaries, and not the reverse. For instance, the base of the Rupelian Stage was adjusted after the fact to correspond to the base of the Oligocene Series (Brinkhuis and Visscher, 1995; Aubry et al., 1999). In like manner the base of the Aquitanian Stage was adjusted after the fact to correspond to the base of the Miocene Series, itself adjusted to coincide with the base of the Neogene System (Aubry et al., 1999). This is in contrast with the ISSC International Guide, which recommends that series boundaries be based on existing stage boundaries (Hedberg, 1976, p. 25, 71, 73; Aubry et al., 1999, p. 110).

A large part of the marine stratigraphic community has long recognized that the base of the Eocene Series corresponds to the base of the Ypresian Stage (Fig. 1, columns A and F; Fig. 3), itself defined by the base of the Mont Héribu Member in Belgium (or its correlative base of the Walton Member of the London Clay Formation in England; see above). With the revision of the concept of the Eocene, this relationship could be maintained only by lowering the base of the Ypresian Stage to a level that is $\sim 0.8-1$ m.y. older than the historically and presently recognized base of the stage (Fig. 3, option 1). This would have a number of unsuitable consequences. First, it would create further terminologic and conceptual confusion, 
blurring even more the unfortunate situation described above. Second, the base of the GSSP-defined Ypresian Stage would lie within the Thanetian Stage, according to the almost universally accepted definition of Renevier. Third, the expanded Ypresian Stage would be defined in a manner that would disconnect it from the unit-stratotype in Belgium, and indeed, there would be no stratigraphic relevance between the GSSP boundary and the unit-stratotype. And fourth, and most regrettably, we would lose the possibility to enhance the stratigraphic resolution of this vitally important, highly informative interval with an identity of its own (Fig. 4). In recognition of this fact, the same meeting of the Working Group of the Paleocene/Eocene Boundary in Paris (1998) that favored lowering the Paleocene/ Eocene boundary to the level of the CIE, also recommended retention of the historical definition of the Ypresian Stage and insertion of a new stage for the (chrono)stratigraphic interval between the CIE and the base of the Ypresian, in order to reconcile the redefined concept of Eocene with existing stage hierarchy (Fig. 3, options 2 and 3).
Although the current ICS revised guidelines are not primarily concerned with historical precedence and, furthermore, have largely eliminated the role of the unit stratotype in favor of the boundary stratotype, we do not believe that chronostratigraphic standards should be erected de novo. Instead, we believe that chronostratigraphy is best served when new standards are defined in harmony with old ones. The advantages and disadvantages of the different options for reconciliation in this particular instance are discussed below.

\section{Chronostratigraphic options}

It is now recognized that there is a distinct stratigraphic gap at the base of the unit stratotype of the Ypresian Stage in northwest Europe (Pomerol, 1988). This hiatus in the type area has generated the argument that the base of the Ypresian Stage could logically be located older than the level currently used (Remane, 2000), and could in fact be equally well defined at a level corresponding to the PETM, thus maintaining the present termi-

\begin{tabular}{|c|c|c|c|c|c|c|c|c|}
\hline \multirow{2}{*}{$\begin{array}{c}\text { EPOCH } \\
\text { SERIES }\end{array}$} & \multirow{2}{*}{ STAGE } & \multirow{2}{*}{$>2000$} & \multicolumn{6}{|c|}{ OPTION } \\
\hline & & & 1 & 2 & 3 & 4 & & \\
\hline $\begin{array}{l}\text { ய } \\
\text { யூ } \\
\text { ○ூ }\end{array}$ & 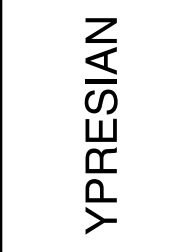 & \multirow{2}{*}{ 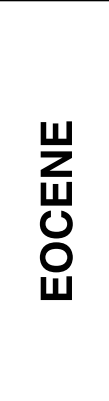 } & \multirow{2}{*}{$\begin{array}{l}z \\
\frac{z}{\omega} \\
\Psi \\
\tilde{n} \\
\frac{\pi}{>}\end{array}$} & 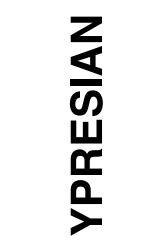 & $\begin{array}{l}z \\
\frac{z}{n} \\
\underset{u}{\alpha} \\
\frac{\tilde{\alpha}}{\alpha}\end{array}$ & \multirow{2}{*}{ 岕 } & \multirow{2}{*}{ 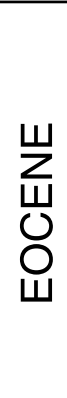 } & \multirow{2}{*}{$\stackrel{\Upsilon}{\dddot{\Psi}}$} \\
\hline \multirow{4}{*}{ 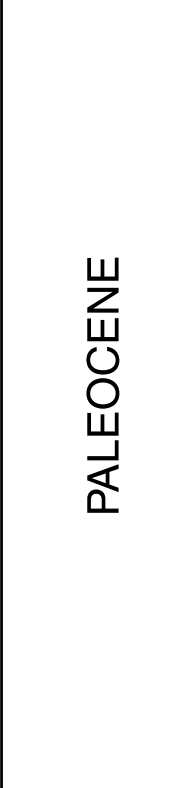 } & Z & & & $\begin{array}{c}\text { SPAR- } \\
\text { NACIAN }\end{array}$ & $\begin{array}{c}\text { NEW } \\
\text { STAGE }\end{array}$ & & & \\
\hline & 京 & \multirow{3}{*}{ 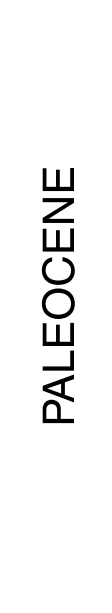 } & \multicolumn{4}{|c|}{ THANETIAN } & \multirow{3}{*}{ 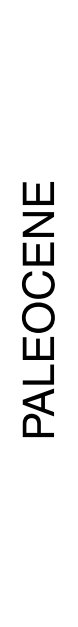 } & $\begin{array}{l}\frac{r}{山} \\
\frac{0}{n}\end{array}$ \\
\hline & $\frac{z}{\frac{z}{0}}$ & & \multicolumn{4}{|c|}{ SELANDIAN } & & 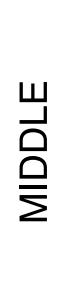 \\
\hline & DANIAN & & \multicolumn{4}{|c|}{ DANIAN } & & 岂 \\
\hline
\end{tabular}

Figure 3. Options for accommodating a newly Global Standard Stratotype-section and Point-defined Paleocene/Eocene boundary. The authors favor Option 2, i.e., the reintroduction of Sparnacian as the lowest standard stage of the newly modified Eocene. Alternatively, a new name (option 3) might be introduced if Sparnacian should prove undesirable in use. 
nology in which the Ypresian is the basal stage of the Eocene. This view, however, ignores monographic studies of the Ypresian stratotype (Dupuis et al., 1991, i.al.) and currently accepted practice (see studies in Knox et al., 1996; de Graciansky et al., 1998), in which the physical stratigraphic limits of the Ypresian synthem have been translated into regional (and global) chronostratigraphy. Furthermore, the hiatus below the unit stratotype does not represent "unoccupied territory" into which the boundary could be moved without repercussions.
If the base Ypresian Stage is lowered to the level of the CIE (Fig. 3, option 1), it will in fact be at a stratigraphic level well within the Thanetian Stage as commonly understood (i.e., that of Renevier, non Dollfus), requiring the Woolwich and Reading Series and Basement Bed of the London Clay, not to mention the Lignites du Soissonnais and Sables de Sinceny, to henceforth bear the name "Ypresian." In the stratigraphic literature, collections, maps and other documents dating back over a century, the integrity of the Thanetian with regard to the Ypresian has been

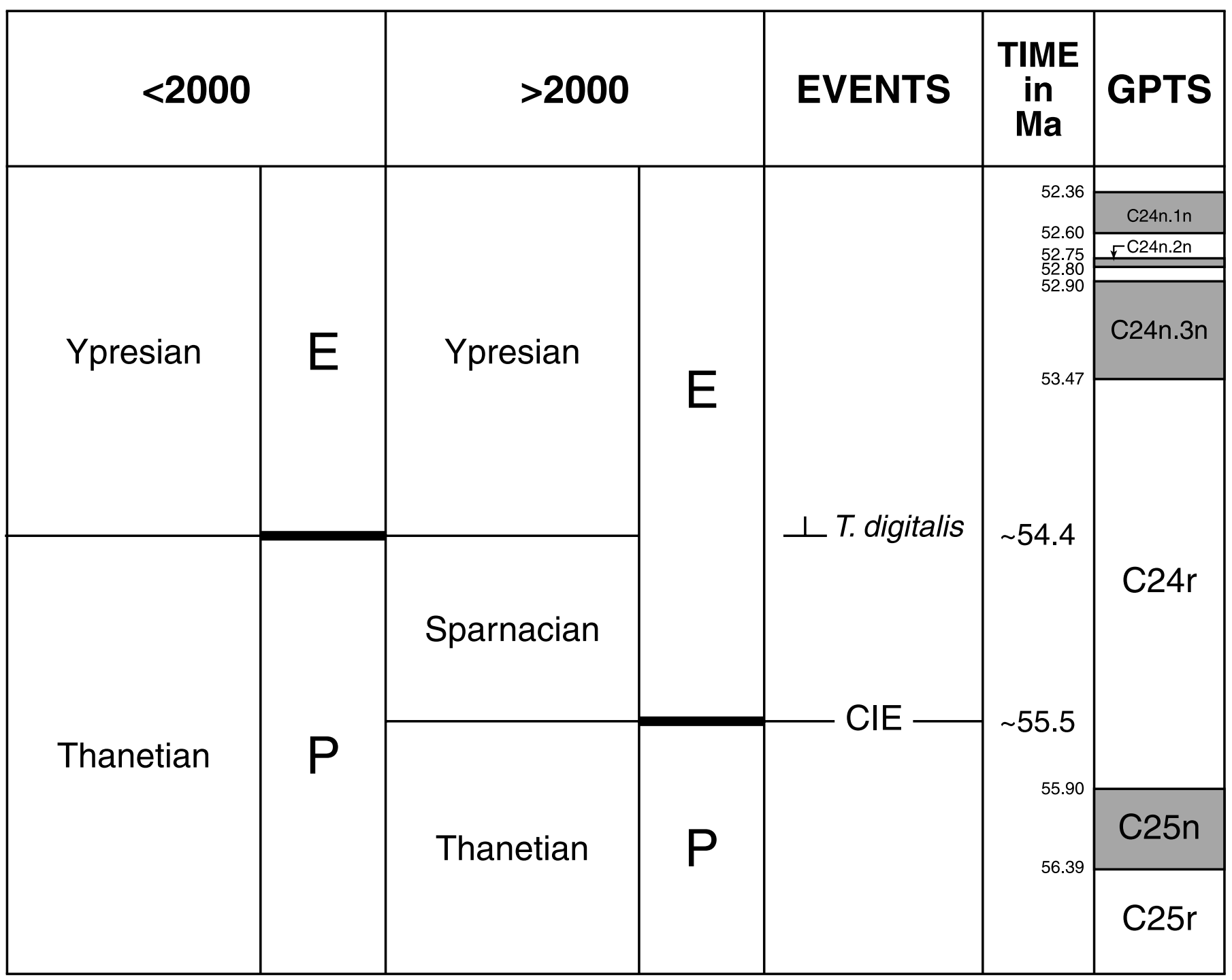

Figure 4. Lower Paleogene chronostratigraphy if the Sparnacian is inserted as the lowest Eocene stage (between Thanetian and Ypresian) as required by newly defined Paleocene/Eocene boundary. The Sparnacian Stage is essentially the (chrono)stratigraphic interval bracketed by the CIE (carbon isotope excursion) and the FAD (First Appearance Datum) of the calcareous nannoplankton Tribrachiatus digitalis. The age estimates of 55.5 Ma and 54.4 Ma for the CIE and FAD of Tribrachiatus digitalis, respectively, are based on the time scale of Berggren et al. (1995). Recent astrochronologic estimates suggest that the CIE may actually be closer to $55 \mathrm{Ma}$ and the FAD of T. digitalis ( base Ypresian) may be $0.8-1.0$ m.y. younger (Cramer, 2002). Tribrachiatus digitalis occurs in the upper part of the Harwich Formation just below the Walton Member at the base of the London Clay Formation. The FAD of this species thus very closely approximates the base of the Ypresian stage in its stratotypic area of northwest Europe. GPTS—geomagnetic polarity time scale. 
axiomatic. The confusion that would result from simply substituting one familiar and strongly characterized stage name for the other in the dense literature of this interval would be unacceptable to most European stratigraphers.

In addition, the lowering of the base of the Ypresian Stage into the upper levels of the previous system seriously conflicts with the strong understanding of the terms Ypresian and Thanetian Age/Stages as corresponding to marine transgressions of geohistorical significance (Aubry et al., 1999). Of all the possible compromises required by the new concept of the Eocene, the temporal distortion of the Ypresian Age by almost 20\%, to absorb $>30 \%$ of the Thanetian seems to be the least desirable in principle and on geohistorical grounds.

On the other hand, as we have discussed above, the original definition of the Sparnacian (Dollfus, 1880) is as a chronostratigraphic unit between a more restricted Thanetian (sensu Dollfus) and the normal Ypresian Stage (Fig. 1, columns A, B and E). Dollfus explicitly and correctly correlated the Paris Basin deposits that embodied his 1880 Sparnacian to the (marginal marine) successions of the Woolwich-Reading Beds in the London Basin (Aubry, 2000). The original base of the Sparnacian, as exposed in outcrops in the western Paris Basin, is closely correlated with the CIE (Fig. 4; Sinha and Stott, 1993a, 1993b; Stott et al., 1996; Sinha et al., 1996). This usage unites marine and terrestrial chronostratigraphy, even though the initial correlation of base Wasatchian NALMA with the Conglomérat de Meudon was incorrect (Sinha et al., 1996; see Aubry, 2000).

We note that the term Neustrian, in place of the continental version of the Sparnacian, has been recently reintroduced by vertebrate paleontologists (Hooker, 1996, 1998; Lucas, 1998) as a European Land-Mammal Age to which the Conglomérat de Meudon fauna is assigned. The Sparnacian is thus released from collateral service as a land mammal age and becomes fully available as a global chronostratigraphic term (Fig. 3, option 2). Despite its somewhat checkered past, in which the Sparnacian has suffered from inconsistent definitions, as well as an uncertain identity ("stage," "lithofacies," "biochronologic unit," "continental stage"), the original concept (Dollfus, 1880) of a stage that encompassed shallow-marine strata is clear, and can be readily restored with reference to unit and boundary stratotypes that conform to the modern guidelines (Hedberg, 1976; Cowie et al., 1986).

The Sparnacian has been criticized in discussions as being too short (c. 1 m.y.) to be useful in global chronostratigraphy. In fact, shorter ages, reflecting the improved resolution in such geochronometric tools as stable isotope curves, magnetostratigraphy, and cyclostratigraphy, are becoming essential for worldwide recognition of distinctive periods (e.g., Gelasian, Ionian and Sicilian stages, cf. Van Couvering, 1997). In this instance, the base of the Sparnacian, in a GSSP-linked to the onset of the CIE, could be resolved to within $\sim 10-20$ k.y. in any part of the world, and cyclostratigraphy and stable isotope stratigraphy allow internal chronostratigraphic resolution of similar order in marine (Bains et al., 1999; Röhl et al., 2000; Cramer, 2001) as well as in terrestrial systems (Bowen et al., 2001). If the test of useful duration of a stage is how far its time span exceeds the error in dating its boundary, the Sparnacian rates higher than most other stages. We note that if for any reason the name Sparnacian, for the orphaned upper Thanetian strata above the new Paleocene/ Eocene boundary, proves unacceptable to the stratigraphic community, another new name for this interval would be preferable to moving the Thanetian/Ypresian boundary and thereby increasing the terminological confusion of the past decades (Fig. 3, option 3). In Table 1 we show that the stratigraphic interval encompassing the Sparnacian Stage varies from several meters to several hundred meters in marine depositional environments to $\sim 1000 \mathrm{~m}$ in some terrestrial settings.

Substitution of a new superstage for the entire interval between the CIE and the middle Eocene (Lutetian Stage) (Fig. 3, option 4) might, at first glance, be seen as a suitable means of providing a clear and unambiguous break from the terminological confusion of the past four decades while at the same time allowing the term Ypresian to be retained without departing from its historical definition by keeping it as a regional stage (along with the Sparnacian). However, it will be readily seen that this approach merely coarsens resolution at the stage level rather than refining it (since it would span an interval of $\sim 6.5$ m.y.), while at the same time requiring the (re)introduction/(re)insertion of the Sparnacian as a local/regional stage to fill the gap between the $\mathrm{CIE}$ and the Ypresian. This approach would furthermore require eventual modification/reduction of all other Paleogene and Neogene "stages" to local/regional status. Paleogene and Neogene Stratigraphic Subcommissions have recently introduced GSSPs for numerous global stage units and this modification of the connotation of a fundamental chronostratigraphic unit is not likely to be met with favor.

\section{Legitimacy of stage/ages as the basis of chronostratigraphy}

In the continuing discussions about rectifying the relationship of the classical European stages and the new Paleocene/ Eocene boundary, we have encountered a strongly held opinion among some colleagues that ages/stages have no correlation value outside of their local domains, even though their names may be applied for essentially sentimental reasons to the global time scale. In this view, the effort to work out resolution of the stage problem is pointless, and the appropriate solution is simply to retrofit the lower Eocene subseries to the enlarged interval between the new boundary and the base of the middle Eocene (currently the base of the Lutetian). Within this framework there would be no need to clarify the stratigraphic relationship of the Ypresian, Sparnacian or Thanetian with regard to the base of the Eocene, since only their names would be required to fill in arbitrary blanks.

In effect, this approach accepts the series, not the stage, as the basic unit in chronostratigraphy (Fig. 3, option 5). Hence, the subseries is a post hoc subdivision of series, without independent calibration beyond its internal middle and upper di- 
TABLE 1. APPROXIMATE THICKNESS OF THE STRATIGRAPHIC INTERVAL BETWEEN CARBON ISOTOPE EXCURSION AND BASE YPRESIAN STAGE* IN DIFFERENT GEOLOGICAL AND/OR SEDIMENTOLOGICAL SETTINGS

\begin{tabular}{|c|c|c|}
\hline Location & Geological setting & Thickness (m) \\
\hline \multicolumn{3}{|l|}{ Atlantic Coastal Plain } \\
\hline 1. Bass River Corehole & Marls, continental shelf & $\sim 12$ \\
\hline 2. Ancora corehole & Marls, continental shelf & $\sim 9$ \\
\hline Alabama & Tuscahoma Sands (nearshore sands) & $\sim 23$ \\
\hline \multicolumn{3}{|l|}{ North Sea Basin§ } \\
\hline \multicolumn{3}{|l|}{ 1. Sele Formation to base Balder Formation } \\
\hline 2. Outer Moray Firth & subordinate; sandstones & $\sim 350-400$ \\
\hline \multicolumn{3}{|l|}{ London-Hampshire Basin } \\
\hline 1. Whitecliff Bay, Isle of Wight & Woolwich-Reading Formation, brown silty clays & $\sim 45-47$ \\
\hline 2. London Basin & Woolwich-Reading Beds, fluvio-deltaic & $\sim 5-15$ \\
\hline \multicolumn{3}{|l|}{ Paris Basin" } \\
\hline 1. Limay Quarry (West Paris Basin) & Argile plastique, paludal & $\sim 15$ \\
\hline \multicolumn{3}{|l|}{ Belgium Basin** } \\
\hline 1. Kallo borehole & Shallow marine sands, clays & $\sim 23$ \\
\hline \multicolumn{3}{|l|}{ Austriat† } \\
\hline 1. Salzburg & Anthering Formation, Gosau Basin (flysch basin) & $\sim 100$ \\
\hline \multicolumn{3}{|c|}{ 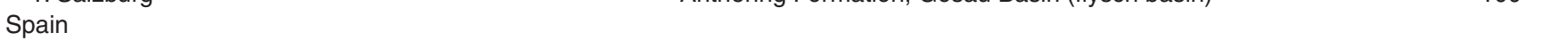 } \\
\hline 1. Zumaya & Turbidite sands & $\sim 12$ \\
\hline 2. Alamedilla & Deep-sea marls & $\sim 7$ \\
\hline \multicolumn{3}{|l|}{ Israel } \\
\hline 1. Ben Gurion & Marine marls (shelf) & $\sim 11$ \\
\hline 2. Zonet Telalim & Same & $\sim 2.3$ \\
\hline \multicolumn{3}{|l|}{ Egypt (Upper Nile Valley) } \\
\hline 1. Dababiya & outer shelf-upper slope; marls & $\sim 42$ \\
\hline 2. Qeriya & Same & $\sim 22$ \\
\hline 3. Gebel Gurnah/Oweina & Same & $>36$ \\
\hline
\end{tabular}

vision boundaries, and the stage in turn has no global application, except as a name given to a post hoc subdivision of a subseries.

Apart from the violence that this does to the hierarchical logic recommended in both the International Guide (Hedberg, 1976) and, ostensibly, in the ICS revised guidelines (Cowie et al., 1986) this option would abandon the advantages of a chronostratigraphy based on stages/ages of relatively short duration, with boundaries made ever more useful by continuing ad- vances in the precision and accuracy of correlation tools, in favor of a relatively coarse system in which only series boundaries would be independently defined and dated. Assumptions that series boundaries are more precise than stage boundaries, simply because it is easier to distinguish elements of one series from another, or possess greater significance because series boundaries are supposedly based on more important criteria than stage boundaries, are illusory, at least in the Cenozoic. It is only realistic to note that any stratigraphic feature that reflects a globally 
significant event, appropriate for a series GSSP, is also certain to be the basis of a stage in a regional section. There is thus nothing to be gained from claiming that only series boundaries based on such features have worldwide correlatibility, and much to be lost because there are clearly more globally correlatable boundary criteria than there are series to fit them.

\section{THE INTRODUCTION OF A NEW CHRONOSTRATIGRAPHIC UNIT}

In recommending the term Sparnacian as a standard stage in the Paleogene chronostratigraphic hagiography, we must acknowledge that the inconsistent usage of the term has caused it to be generally (but not completely) ignored as a chronostratigraphic term, in favor of extending the Thanetian up to the base of the Ypresian London Clay Formation (Berggren, 1971; Berggren and Aubry, 1996, 1998). However, it is clear that the decision to lower the Paleocene/Eocene boundary to be coincident with the negative $\delta^{13} \mathrm{C}$ excursion makes the upper third of Renevier's expanded Thanetian early Eocene in age. Reassigning this amputated interval to Ypresian has the undesirable effect of concealing, rather than illuminating, the fact that the boundary had been moved to a significantly older level. The least confusion, and the greatest respect for the stability of the literature, requires the insertion of a formal stage between the Thanetian (sensu limito) and the Ypresian (s.s.) to accommodate the redesignated interval.

The restoration of the Sparnacian Stage, which in its original definition is essentially equivalent to the redesignated interval, seems to be the most appropriate, if not the only possible, choice for the identification of this crucial interval (Fig. 4). Furthermore, it must be recognized that this, the basal stage of the Eocene in its conceptual home of the Paris-London Basin (Lyell, 1833), would necessarily be regarded as having the special status of a "global standard stage" or defining hierarchical component of the Eocene Series. In accord with the hierarchical logic that requires that the base of this unit defines the base of the higher unit (Hedberg, 1976), and following the precedent of the Calabrian Stage and the Pliocene/Pleistocene boundary (Van Couvering, 1997), we consider that the boundarystratotype of this basal stage will automatically be created by the adoption of a GSSP for the Paleocene/Eocene boundary, without further action.

The authors of this paper most of whom are members of the Working Group on the Paleocene/Eocene boundary that voted in favor of the revised Eocene concept, endorse the recommendation that a new stage, preferably the Sparnacian Stage restored to the original sense of Dollfus (1880), should be adopted for that former part of the classical Paleocene that now becomes the lowest part of the Eocene (Fig. 4). In fact, if we accept hierarchical logic and precedent, the approval of a GSSP for the base of the Eocene Series must simultanously establish the GSSP for the Sparnacian Stage in the worldwide chronostratigraphic hierarchy.

\section{ACKNOWLEDGMENTS}

The information and ideas presented here represent the outgrowth of over a decade of discussions amongst the members of the Working Group of the Paleocene/Eocene Boundary of the International Subcommission on Paleogene Stratigraphy as well as with other members of the stratigraphic community. The ideas expressed here were presented at the meeting on Paleogene Climates in Powell, Wyoming, in July 2001, organized by the Smithsonian Institution National Museum of Natural History. We wish to express our heartfelt thanks to Scott Wing, coordinator of the meeting, and to the many members of the stratigraphic community at large who, over the years, have engaged us in an ongoing dialogue regarding chronostratigraphic philosophy and methodology and the terminology and nomenclature associated with the placement of the Paleocene/Eocene boundary. We warmly thank Mike Woodburne for thorough discussion on the content and presentation of this manuscript. We thank him, Ellen Thomas and an anonymous reviewer for their critical and constructive review of the manuscript. In addition, Steven Walsh's comments on an incomplete draft contained some stimulating points. Our field research and the participation of several of us (MPA, WAB and $\mathrm{KO}$ ) at the Powell meeting was supported, in part, by a grant from the National Geographic Society. This is Woods Hole Oceanographic Institution Contribution Number 10710 .

\section{REFERENCES CITED}

Ali, J.R., King, C., and Hailwood, E.A., 1993, Magnetostratigraphic calibration of early Eocene depositional sequences in the southern North Sea Basin, in Hailwood, E.A., and Kidd, R.B., eds., High-resolution stratigraphy: Geological Society [London] Special Publication 70, p. 99-125.

Archibald, J.D., Gingerich, P.D., Lindsay, E.H., Clemens, W.A., Krause, D.W., and Rose, K.D., 1987, First North American Land Mammal Ages of the Cenozoic era, in Woodburne, M.O., ed., Cenozoic mammals of North America: Berkeley, California, University of California Press, p. 24-76.

Aubry, M.-P., 1996, Toward an upper Paleocene-lower Eocene high-resolution stratigraphy, in Aubry, M.-P., and Benjamini, C., eds., Paleocene/Eocene boundary events in space and time: Israel Bulletin of Earth Sciences, v. 44, p. 239-253.

Aubry, M.-P., 2000, Where should the global stratotype section and point (GSSP) for the Paleocene/Eocene boundary be located?: Bulletin de la Société Géologique de France, v. 171, no. 4, p. 461-476.

Aubry, M.-P., and Berggren, W.A., 2000a, When conflict arises between principles and rules: The case of the GSSP for the Paleocene/Eocene boundary: GFF (Geologiska Föreningens i Stockholm Förhandlingar) (Journal of the Geological Society of Sweden), v. 122, p. 13-14.

Aubry, M.-P., and Berggren, W.A., 2000b, The homeless GSSP: The dilemma of the Paleocene/Eocene boundary: Tertiary Research, v. 20, no. 1-4, p. 107-112.

Aubry, M.-P., Berggren, W.A., Stott, L., and Sinha, A., 1996, The upper Paleocenelower Eocene stratigraphic record and the Paleocene-Eocene boundary carbon isotopre excursion: Implications for geochronology, in Knox, R.W.O'B., et al., eds., Correlation of the early Paleogene in northwestern Europe: London, Geological Society Special Publication 101, p. 353-380.

Aubry, M.-P., Berggren, W.A., Van Couvering, J.A., and Steininger, F., 1999, Problems in chronostratigraphy: Stages, series, unit and boundary strato- 
types, global stratotype section and point and tarnished golden spikes: Earth Science Reviews, v. 46, p. 99-148.

Aubry, M.-P., Van Couvering, J.A., Berggren, W.A., and Steininger, F., 2000a, Should the golden spike glitter?: Episodes, v. 23, no. 3, p. 203-210.

Aubry, M.-P., Cramer, B., Miller, K.G., Wright, J., Kent, D.V., and Olsson, R.D., 2000b, Late Paleocene event chronology: Unconformities not diachrony: Bulletin de la Société Géologique de France, v. 171, p. 367-378.

Aubry, M.-P., and the Working Group on the Paleocene/Eocene Boundary, 2002, The Paleocene/Eocene boundary global standard stratotype-section and point (GSSP): Criteria for characterisation and correlation: Tertiary Research, v. 21 , no. $1-4$, p. $57-70$.

Bains, S., Corfield, R.M., and Norris, R.D., 1999, Mechanisms of climate warming at the end of the Paleocene: Science, v. 285, p. 724-727.

Berggren, W.A., 1971, Tertiary Boundaries, in Funnel, B.M., and Riedel, W.R., eds., Micropaleontology of the oceans: Cambridge, UK, Cambridge University Press, p. 693-808.

Berggren, W.A., and Aubry, M.-P., 1996, A late Paleocene-early Eocene northwest European and North Sea magnetobiochronological correlation network, in Knox, R.W.O'B., et al., eds., Correlation of the early Paleogene in northwestern Europe: London, Geological Society Special Publication 101, p. 309-352.

Berggren, W.A., and Aubry, M.-P., 1998, The Paleocene/Eocene Epoch/Series boundary: Chronostratigraphic framework and estimated geochronology, in Aubry, M.-P., et al., eds., Late Paleocene-early Eocene climatic and biotic events in the marine and terrestrial records: New York, Columbia University Press, p. 18-36.

Berggren, W.A., Kent, D.V., and Flynn, J.J., 1985, Paleogene geochronology and chronostratigraphy, in Snelling, N.J., ed., The chronology of the geological record: London, Geological Society Memoir 10, p. 141-195.

Berggren, W.A., Kent, D.V., Swisher, C.C., III, and Aubry, M.-P., 1995, A revised Cenozoic geochronology and chronostratigraphy, in Berggren, W.A., et al., eds., Geochronology, time-scales, and global stratigraphic correlation: SEPM (Society for Sedimentary Geology) Special Publication 54, p. 129-212.

Berggren, W.A., Lucas, S., and Aubry, M.-P., 1998, Late Paleocene-early Eocene climatic and biotic evolution, in Aubry, M.-P., et al., eds., Late Paleocene-early Eocene climatic and biotic events in the marine and terrestrial records: New York, Columbia University Press, p. 1-17.

Bowen, G.J., Koch, P.L., Gingerich, P.D., Norris, R.D., Bains, S., and Corfield, R.M., 2001, Refined isotope stratigraphy across the continental Paleocene-Eocene boundary on Polecat Bench in the northern Bighorn Basin, in Gingerich, P.D., ed., Paleocene-Eocene stratigraphy and biotic change in the Bighorn and Clarks Fork Basins, Wyoming: Ann Arbor, Michigan, University of Michigan Papers on Paleontology, v. 33, p. 7388.

Brinkhuis, H., and Visscher, H., 1995, The upper boundary of the Eocene Series: A reappraisal based on dinoflagellate cyst biostratigraphy and sequence stratigraphy, in Berggren, W.A., et al., eds., Geochronology, time scales, and global stratigraphic correlations: SEPM (Society for Sedimentary Geology) Special Publication 54, p. 295-304.

Bujak, J.P., and Brinkhuis, H., 1998, Global warming and dinocyst changes across the Paleocene/Eocene boundary, in Aubry, M.-P., et al., eds., Late Paleocene-early Eocene climatic and biotic events in the marine and terrestrial records: New York, Columbia University Press, p. 277-295.

Cavelier, C., and Pomerol, C., 1986, Stratigraphy of the Paleocene: Bulletin de la Société Géologique de France, ser. 8, v. 2, no. 2, p. 255-265.

Cavelier, C., and Roger, J., editors, 1980, Les Etages Français et leurs Stratotypes: Mémoires du Bureau de Recherches Géologiques et Minières, no. $109,295 \mathrm{p}$.

Cowie, J.W., Ziegler, W., Boucot, A.J., Bassett, M.G., and Remane, J., 1986, Guidelines and statutes of the International Commission on Stratigraphy: Courier Forschungsinstitut Senckenbergiana, v. 83, p. 1-9.

Cramer, B.S., 2001, Latest Paleocene-earliest Eocene cyclostratigraphy using core photographs for reconnaisance in geophysical logging: Earth and Planetary Science letters, v. 186, p. 231-244.
Cramer, B.S., 2002, Milankovitch cycles and comet catastrophes: Carbon isotope variations in the Late Paleocene-eartly Eocene: Ph.D. thesis, Rutgers University, $116 \mathrm{p}$.

Cramer, B.S., Aubry, M.-P., Miller, K.G., Olsson, R.K., Wright, J.D., and Kent, D.V., 1999, An exceptional chronologic, isotopic, and clay mineralogic record of the latest Paleocene thermal maximum, Bass River, NJ, ODP 174AX: Bulletin de la Société Géologique de France, v. 170, p. 883-897.

Crouch, E.M., 2001, Environmental change at the time of the Paleocene-Eocene biotic turnover: Utrecht, Netherlands, Laboratory of Palaeobotany and Palynology Contributions Series, v. 14, 216 p.

Crouch, E., Heilmann-Clausen, C., Brinkhuis, H., Morgans, H.E.G., Rogers, K.M., Egger, H., and Schmitz, B., 2000, Global dinoflagellate event associated with the late Paleocene thermal maximum: Geology, v. 29, p. 315318.

Curry, D., Adams, C.G., Boulter, M.C., Dilley, F.C., Eames, F.E., Funnell, B.M., and Wells, M.K., 1978, A correlation of Tertiary rocks in the British Isles: Geological Society [London] Special Report 12, p. 1-72.

De Coninck, J., Geets, S., and Willems, W., 1983, The Mont Héribu Member: Base of the Ieper Formation in the Belgian Basin: Tertiary Research, v. 5, no. 2, p. 83-104.

de Graciansky, P.-C., Hardenbol, J., and Vail, P.R., editors, 1998, Mesozoic and Cenozoic sequence stratigraphy of European basins: SEPM (Society for Sedimentary Geology) Special Publication 60, 768 p.

Dollfus, G., 1880, Essai sur l'extension des terrains tertiaires dans le Bassin anglo-parisien: Bulletin de la Société Géologique de Normandie, Le Havre, v. VI (1879), p. 584-605.

Dollfus, G., 1905, Critique de la classification de l'Eocène inférieur (Lettre de M.G. Dollfus à M. Mce Leriche): Annales de la Société Géologique du Nord, v. 34, p. 373-382.

Dumont, A.H., 1839, Rapport sur les travaux de la carte géologique en 1839, avec une carte géologique des environs de Bruxelles: Bulletin de l' Académie du Royaume de Belgique, Classe Sciences, v. 6, p. 464-485.

Dumont, A.H., 1849, Rapport sur la carte géologique du Royaume: Bulletin de l'Académie du Royaume de Belgique, Classe Sciences, v. 16, p. 351-373.

Dupuis, C., De Coninck, J., and Steurbaut, E., editors, 1991, The Ypresian stratotype: Bulletin de la Société Belge de Géologie, v. 97, no. 3/4, 481 p.

Egger, H., Heilmann-Clausen, C., and Schmitz, B., 2000, The Paleocene/Eocene boundary interval of a Tethyan deep-sea section (Austria) and its correlation with the North Sea basin: Bulletin de la Société Géologique de France, v. 171 , no. 2, p. 207-216.

Ellison, R.A., Knox, R.W.O’B., Jolley, D.W., and King, C., 1994, A revision of the lithostratigraphical classification of the early Palaeogene strata of the London Basin and East Anglia: Proceedings of the Geologists' Association, v. 105, p. 187-197.

Feugueur, L., 1963, L'Yprésien du Bassin de Paris: Mémoire explicatif de la Carte géologique détaillée de la France: Orléans, France, Bureau de Recherches Géologiques et Minières, 568 p.

Frederiksen, N.O., 1994, Paleocene floral diversities and turnover events in eastern North America and their relation to diversity models: Review of Palaeobotany and Palynology, v. 82, p. 225-238.

Gingerich, P.D., 1989, New earliest Wasatchian mammalian fauna from the Eocene of northwestern Wyoming: Composition and diversity in a rarely sampled high-floodplain assemblage: University of Michigan Papers on Paleontology, v. 28, p. 1-97.

Gingerich, P.D., 2001, Biostratigraphy of the continental Paleocene-Eocene boundary interval on Polecat Bench in the northern Bighorn Basin, in Gingerich, P.D., ed., Paleocene-Eocene stratigraphy and biotic change in the Bighorn and Clarks Fork Basins, Wyoming: University of Michigan Papers on Paleontology, v. 33, p. 37-71.

Granger, W., 1914, On the names of lower Eocene faunal horizons of Wyoming and New Mexico: Bulletin of the American Museum of Natural History, v. 33, p. 201-207.

Harland, W.B., Armstrong, R.L., Cox, A.V., Craig, L.E., Smith, A.G., and Smith, D.G., 1990, A geologic time scale 1989 (revised edition): Cambridge, UK, Cambridge University Press, 263 p. 
Hedberg, H.D., editor, 1972, An international guide to stratigraphic classification, terminology, and usage: Lethaia, v. 5, p. 283-295 (reprinted from International Subcommission on Stratigraphic Classification, Report No. 7).

Hedberg, H.D., editor, 1976, International stratigraphic guide: A guide to stratigraphic classification, terminology, and procedure: New York, John Wiley and Sons, $200 \mathrm{p}$.

Heilmann-Clausen, C., and Egger, H., 2000, The Anthering outcrop (Austria): A key-section for correlation between Tethys and northern Europe near the Paleocene/Eocene boundary: GFF (Geologiska Föreningens i Stockholm Förhandlingar) (Journal of the Geological Society of Sweden), v. 22, p. 69.

Hooker, J.J., 1996, Mammalian biostratigraphy across the Paleocene-Eocene boundary in the Paris, London and Belgian Basins, in Knox, R.W.O'B., et al., eds., Correlation of the early Palaeogene in northwest Europe: London, Geological Society Special Publication 101, p. 219-254.

Hooker, J.J., 1998, Mammalian faunal change across the Paleocene-Eocene transition in Europe, in Aubry, M.-P., et al., eds., Late Paleocene-early Eocene climatic and biotic events in the marine and terrestrial records: New York, Columbia University Press, p. 428-450.

Jolley, D.W., 1996, The earliest Eocene sediments of eastern England: An ultrahigh-resolution palynological correlation, in Knox, R.W.O'B., et al., eds., Correlation of the early Palaeogene in northwest Europe: London, Geological Society Special Publication 101, p. 219-254.

Kennett, J.P., and Stott, L.D., 1991, Abrupt deep-sea warming, palaeoceanographic changes and benthic extinctions at the end of the Palaeocene: Nature, v. 353 , p. $225-229$.

King, C., 1991, Stratigraphy of the Ieper Formation and Argile des Flandres (early Eocene) in western Belgium and southern France: Bulletin of the Belgium Geological Society, v. 97, p. 349-372.

Knox, R.W.O'B., 1994, From regional to standard stage: Implications for the historical Paleogene stratotypes of northwest Europe: GFF (Geologiska Föreningens i Stockholm Förhandlingar) (Journal of the Geological Society of Sweden), Meeting Proceedings "Stratigraphy of the Paleocene," v. 116, p. $56-57$.

Knox, R.W.O'B., Corfield, R.M., and Dunay, R.E., editors, 1996, Correlation of the early Palaeogene in northwest Europe: London, Geological Society Special Publication 101, $480 \mathrm{p}$.

Laga, P., 1981, Landenian, in Pomerol, C., ed., Stratotypes of Paleogene stages: Bulletin d' Information des Géologues du Bassin de Paris, p. 123-145.

Laurain, M., Barta, L., Bolin, C., Guernet, C., Gruas Cavagnetto, C., Louis, P., Perreau, M., Riveline, J., and Thiry, M., 1983, Le sondage et la coupe du Mont Bernon à Epernay (Marne): Etude sédimentologique et paléontologique du stratotype du Sparnacien et de la série éocène: Géologie de la France, v. 3, p. 235-254.

Lemoine, M., 1891, Etude d' ensemble sur les dents des mammifères fossiles des environs de Reims: Bulletin de la Société Géologique de France, Sér. 3, p. 263-290.

Lemoine, V., 1889, Considérations généraux sur les vertébrés fossiles des environs de Reims et spécialement sur les mammifères de la faune cernaysienne: Comptes Rendus des Séances du Congrès International Zoologique, Paris, 1889, p. 233-279.

Lucas, S.G., 1998, Fossil mammals and the Paleocene/Eocene Series boundary in Europe, North America, and Asia, in Aubry, M.-P., et al., eds., Late Paleocene-early Eocene climatic and biotic events in the marine and terrestrial records: New York, Columbia University Press, p. 451-500.

Lyell, C., 1833, Principles of geology: Being an attempt to explain the former changes of the Earth's surface by reference to causes now in operation: London, John Murray, v. 3, 398 p.

Pomerol, C., 1969, Limite Paléocène-Eocène: Mémoires du Bureau de Recherches Géologiques et Minières, v. 69, p. 447-449.

Pomerol, C., 1977, La limite Paléocène-Eocène en Europe occidentale: Comptes rendus sommaires de la Société Géologique de France, fasc. 4, p. 199-202.

Pomerol, C., editor, 1981, Stratotypes of Paleogene Stages: Bulletin d'Information des Géologues du Bassin de Paris, Mém. hors série, no. 2, 301 p.

Pomerol, C., 1988, Stratigraphy of the Palaeogene: Hiatuses and transitions: Proceedings of the Geologists' Association, v. 100, no. 3, p. 313-324.
Prestwich, J., 1850, On the structure of the strata between the London Clay and the Chalk in the London and Hampshire Tertiary Systems, Part I: Quarterly Journal of the Geological Society [London], v. 6, p. 252-281.

Prestwich, J., 1852, On the structure of the strata between the London Clay and the Chalk in the London and Hampshire Tertiary Systems, Part III: The Thanet Sands: Quarterly Journal of the Geological Society [London], v. 8, p. 235-264.

Prestwich, J., 1854, On the structure of the strata between the London Clay and the Chalk in the London and Hampshire Tertiary Systems, Part II: The Woolwich and Reading Series: Quarterly Journal of the Geological Society [London], v. 10, p. 75-170.

Remane, J., 2000, Comments on the paper of "Should the Golden Spike Glitter?" by M.-P. Aubry et al.: Episodes, v. 23, no. 3, p. 211-213.

Remane, J., Bassett, M.G., Cowie, J.W., Gohrbandt, K.H., Lane, H.R., Michelsen, O., and Naiwen, W., 1996, Revised guidelines for the establishment of global chronostratigraphic standards by the International Commission on Stratigraphy (ICS): Episodes, v. 19, p. 77-81.

Renevier, E., 1873, Tableau des terrains sédimentaires formés pendant les époques de la phase organique du globe terrestre: Bulletin de la Société Vaudoise de Sciences Naturelles, v. 12, no. 70, Table III.

Renevier, E., 1874, Tableau des terrains sédimentaires formés pendant les époques de la phase organique du globe terrestre: Bulletin de la Société Vaudoise de Sciences Naturelles, v. 13, no. 72, p. 218-252.

Röhl, U., Bralower, T.J., Norris, R.D., and Wefer, G., 2000, New chronology for the late Paleocene thermal maximum and its environmental implications: Geology, v. 28, p. 927-930.

Rose, K.D., 1981, The Clarkforkian land-mammal age and mammalian faunal composition across the Paleocene/Eocene boundary: University of Michigan Papers on Paleontology, v. 26, p. 1-197.

Russell, D.E., 1967, Le Paléocène continental d'Amérique du Nord: Mémoires du Muséum National d'Histoire Naturelle, Sér. C, v. 16, p. 1-99.

Russell, D.E., 1968, Succession, en Europe, des faunes mammaliennes au début du Tertiaire: Mémoires du Bureau de Recherches Géologiques et Minières, v. 58, p. 291-296.

Russell, D.E., and Zhai, R., 1987, The Paleogene of Asia: Mammals and stratigraphy: Mémoires du Muséum National d'Histoire Naturelle, Série C, Sciences de la Terre, v. 52, 488 p.

Russell, D.E., Hartenberger, J.L., Pomerol, C., Sen, S., Schmidt-Kittler, N., and Vianey Liaud, M., 1982, Mammals and stratigraphy: The Paleocene of Europe: Palaeovertebrata, Mémoire extraordinaire, p. 1-77.

Salvador, A., editor, 1994, International Stratigraphic Guide: A guide to stratigraphic classification, terminology, and procedure (2nd edition): International Union of Geological Sciences and Geological Society of America, Trondheim, Norway, and Boulder, Colorado, iii-xix, 214 p.

Savage, D.E., and Russell, D.E., 1983, Mammalian paleofaunas of the world: London, Addison-Wesley Publishing Company, 432 p.

Schimper, W.Ph., 1874, Traité de Paléontologie Végétale ou la Flore du Monde Primitif dans ses Rapports avec les Formations Géologiques, v. 3: Paris, J.B. Ballière et Fils, 836 p.

Sinha, A., and Stott, L.D., 1993a, Recognition of the Paleocene/Eocene boundary in the northwestern European stratotype sections on the basis of carbon isotope stratigraphy: Journal of Vertebrate Paleontology, v. 13(3) (Supplement, p. 57A, Abstracts of papers, 53d Annual Meeting of Society of Vertebrate Paleontology).

Sinha, A., and Stott, L.D., 1993b, Recognition of the Paleocene/Eocene boundary carbon isotope excursion in the Paris Basin, France: Symposium on correlation of the early Paleogene in northwest Europe, Geological Society of London Program and Abstracts (1-2 December 1993), 1 p.

Sinha, A., Aubry, M.-P., Stott, L.D., Thiry, M., and Berggren, W.A., 1996, Chemostratigraphy of the "lower" Sparnacian deposits (Argiles plastiques bariolées) of the Paris Basin, in Aubry, M.-P., and Benjamini, C., eds., Paleocene-Eocene boundary events in space and time: Israel Journal of Earth Sciences, v. 44, p. 223-237.

Speijer, R.P., 1994, Extinction and recovery patterns in benthic foraminiferal paleocommunities across the Cretaceous/Paleogene and Paleocene/Eocene 
boundaries: Geologica Ultraiectina, Mededelingen van de Faculteit Aardwetenschappen Universiteit Utrecht, v. 124, 191 p.

Stott, L.D., Sinha, A., Thiry, M., Aubry, M.-P., and Berggren, W.A., 1996, Global $\delta^{13} \mathrm{C}$ changes across the Paleocene-Eocene boundary: Criteria for terrestrial-marine correlations, in Knox, R.W.O'B., et al., eds., Correlation of the early Paleogene in northwest Europe: London, Geological Society Special Publication 101, p. 388-399.

Thiry, M., Dupuis, C., Aubry, M.-P., Berggren, W.A., Ellison, R.A., Knox, R.W.O'B., Sinha, A., and Stott, L., 1998, Tentative correlations between continental deposits of the Argiles Plastiques (Paris Basin) and Reading Beds (London Basin), based on chemostratigraphy: Strata, v. 1, p. 125-129.

Thomas, E., 1998, Biogeography of the late Paleocene benthic foraminiferal extinction, in Aubry, M.-P., et al., eds., Late Paleocene-early Eocene climatic and biotic events in the marine and terrestrial records: New York, Columbia University Press, p. 214-243.

Van Couvering, J.A., 1997, Preface: The new Pleistocene, in Van Couvering, J.A., ed., The base of the Pleistocene and the beginning of the Quaternary: New York, Cambridge University Press, p. iii-X.

von Koenen, A., 1885, Über eine Palaocäne Fauna von Kopenhagen: Abhandlungen Köngliche Gesellschaft Wissenschaften, Göttingen, v. 32, p. 1128.
Walsh, S.L., 2001, Notes on geochronological and chronostratigraphic units: Geological Society of America Bulletin, v. 113, p. 704-713.

Wing, S.L., 1997, Global warming and land species richness: A case study of the Paleocene/Eocene boundary, in Reska-Kudia, M.L., et al., eds., Biodiversity II: Understanding and protecting our biological resources: Washington, D.C., Joseph Henry Press, p. 163-185.

Wing, S.L., Alroy, J., and Hickey, L.J., 1995, Plant and mammal diversity in the Paleocene to early Eocene of the Bighorm Basin: Palaeogeography, Palaeoclimatology, Palaeoecology, v. 115, p. 117-155.

Wing, S.L., Bao, H., and Koch, P., 2000, An early Eocene cool period? Evidence for continental cooling during the warmest part of the Cenozoic, in Huber, B.T., et al., eds., Warm climates in Earth history: New York, Cambridge University Press, p. 197-237.

Wood, H.E., II, Chaney, R.W., Clark, J., Colbert, E.H., Jepsen, G.L., Reeside, J.B., Jr., and Stock, C., 1941, Nomenclature and correlation of the North American continental Tertiary: Geological Society of America Bulletin, v. 52, p. $1-48$.

Manuscript Accepted by the Society August 13, 2002 